\title{
Infrastructure for Digital Connectivity
}

\subsection{InTRODUCTION}

Our economic and social interactions have become increasingly organised around digital information networks that connect people, processes, things, data and networks. Digital connectivity is, of course, a prerequisite for participating in a networked "knowledge economy". In economic terms, digital connectivity brings together businesses and consumers via a web of sophisticated information and communication technology (ICT) applications, such as cloud computing, supply-chain and business-to-business networks (Canzian et al., 2019). However, the impact of digital connectivity extends far beyond the economic sphere. The potential societal benefits of digital connectivity are well illustrated in an EU context, where the European Commission has emphasised digital connectivity as a component of the European Pillar of Social Rights, a set of principles outlined by the European Commission in November 2017 which aims to ensure that EU citizens enjoy equal opportunities and access to the labour market, fair working conditions, and social protection and inclusion. ${ }^{1}$ Furthermore, the availability of a secure and performant sustainable digital infrastructure is one of four pillars of the EU's plans for Europe's digital transformation by 2030. Indeed, the European Commission (202la, p. 5) states.

It is our proposed level of ambition that by 2030, all European households will be covered by a Gigabit network, with all populated areas covered by $5 G$.

\footnotetext{
${ }^{1}$ For further details, see: https://ec.europa.eu/commission/priorities/deeper-and-fairereconomic-and-monetary-union/european-pillar-social-rights_en .

(C) The Author(s) 2022

T. Lynn et al., Digital Towns, https://doi.org/10.1007/978-3-030-91247-5_6
} 
Of course, digital infrastructure aspirations are not confined to the EU. Policymakers across the globe have sought to harness the potential of digital connectivity to drive economic development and improve standards of living. However, while a growing body of evidence now documents the positive impact of digital connectivity across a number of different economic indicators, significant challenges continue to impede the delivery of comprehensive digital connectivity across all social groups and geographical contexts.

\subsection{What Is InFrastructure for Digital Connectivity?}

The definition of digital connectivity is widely debated. These definitions range across a socio-technological spectrum. For example, it can be defined as the relations enabled via digital media technologies (Ponzanesi, 2019) or as the deployment of broadband infrastructure and its quality (Digital Economy and Skills Unit, 2018). In many respects, both definitions are too narrow. The former does not allow for technologies other than digital media while the latter emphasises only one type of connectivity, broadband. Digital connectivity, as the term suggests, cannot be characterised in isolation but rather needs to be viewed as part of a wider digital ecosystem. It needs to accommodate a constantly evolving technology base and a wide range of use cases and contexts. As such, we use the term 'Infrastructure for Digital Connectivity' (IDC) in this chapter to mean the availability and access to infrastructure for using digital technologies.

While policy overwhelmingly focuses on the deployment and quality of telecommunications infrastructure, and specifically broadband, when referring to digital connectivity, this reflects a first world and macro bias. Firstly, it assumes uninterrupted power supply. Over 770 million people worldwide do not have access to electricity, and the overwhelming majority are located in rural areas, primarily in Asia and sub-Saharan Africa (IEA, 2020). As one observer noted: "without energy, the Internet is a black hole" (Rubin, 2017). Secondly, it assumes once telecommunications infrastructure is deployed, citizens and other social institutions will have access to the computing equipment and the skills to use this telecommunications infrastructure. As discussed in Chap. 2, this cannot be assumed. Finally, it assumes freedom to connect to the Internet. As well as 
inequalities resulting from the digital divide, access to the Internet may be subject to state control generally or in specific in specific contexts (Freedom House, 2020).

Against this background, and in the context of this book, towns play an important role in rural communities as (i) they are not only likely to have the prerequisite electricity supply but are more likely to have higher quality telecommunications infrastructure than sparsely populated areas, and (ii) public access to computer equipment and the Internet through civic buildings, libraries, Internet cafes etc. Table 6.1 below briefly summarises key terms and concepts with respect to IDC. For the most part, IDC comprises increasingly mainstream technologies e.g., fixed broadband, 2G-4G wireless networks, and Wi-Fi. However, frontier technologies such as solar photovoltaic energy are providing greater access to power in remote areas (UNCTAD, 2021), while next generation access (NGA) technologies such as $5 \mathrm{G}$ and artificial intelligence are dramatically increasing the availability and quality of broadband access. Furthermore, blockchain technologies are being deployed to enable distributed and shared broadband (Messié et al., 2019; Haleem et al., 2018).

\subsection{ECONOMIC IMPACT OF INFRASTRUCTURE For Digital Connectivity}

In recent years, a growing body of research has sought to estimate the impact of enhanced IDC on economic activity. While headline Gross Domestic Product (GDP) data yields an aggregate estimate of IDC's contribution to economic activity, research has increasingly sought to ascertain the channels through which this contribution emerges-be it at a household level or a firm level; also, at a variety of spatial scales, from local and regional upwards, as well as in distinct geographical and economic contexts. The picture that emerges when one goes beyond the aggregate economic level is one of marked social, spatial, and occupational unevenness in the impact of IDC on economic activity.

\subsubsection{Macro-Level Economic Impact}

A substantial body of evidence now indicates that increased broadband penetration is positively associated with growth in GDP (ITU, 2012; 
Table 6.1 Key terms and concepts in Infrastructure for Digital Connectivity

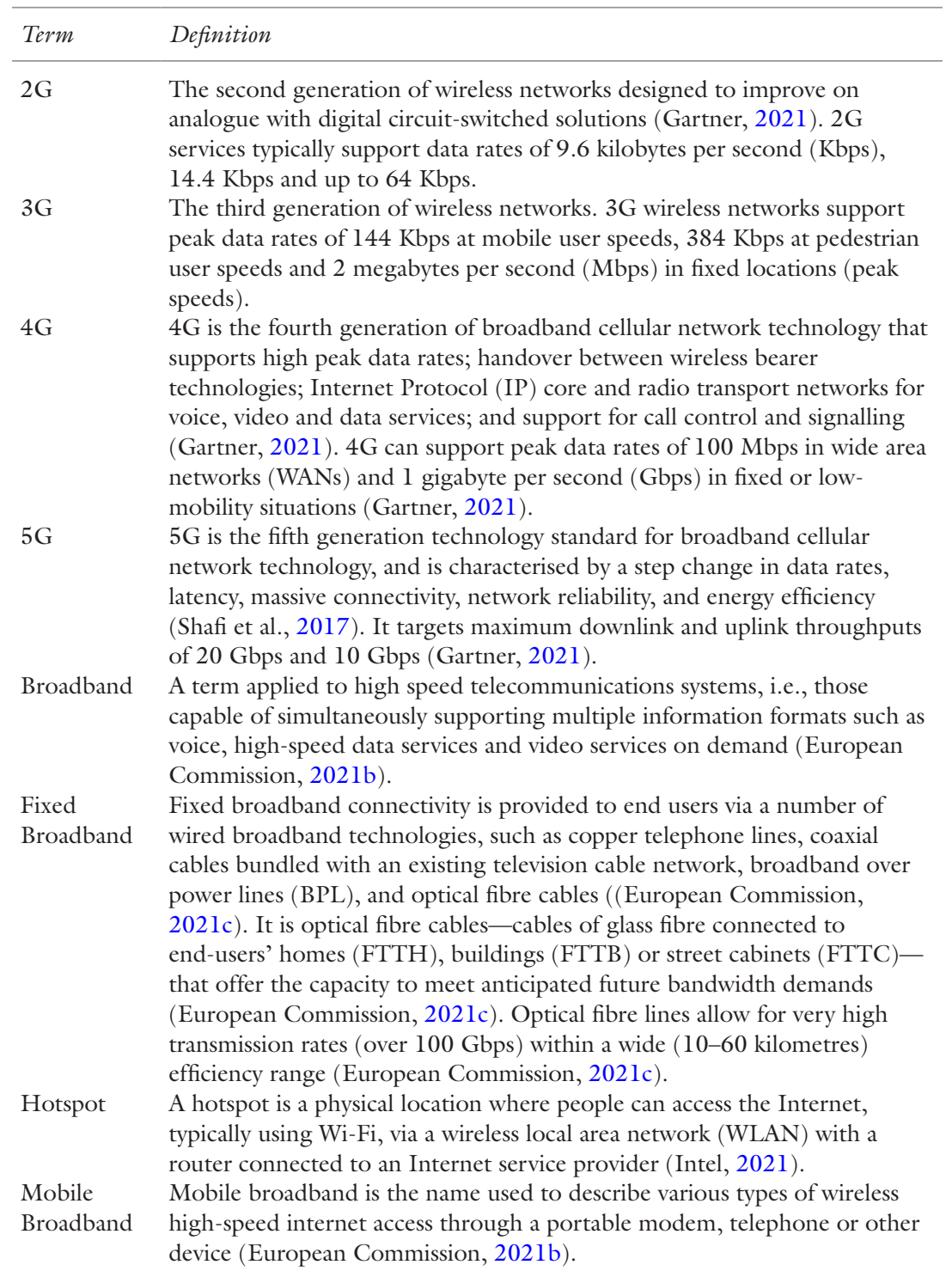


Table 6.1 (continued)

\begin{tabular}{ll}
\hline Term & Definition \\
\hline $\begin{array}{l}\text { Municipal } \\
\text { WiFi }\end{array}$ & $\begin{array}{l}\text { Local networks of wireless Internet access that adhere to } 802.11 \\
\text { technological standards and are built by or for local governments for the } \\
\text { use of the government and the people and business in that area (Jassem, } \\
2010) .\end{array}$ \\
Next & $\begin{array}{l}\text { Access networks which consist wholly or in part of optical elements and } \\
\text { Generation } \\
\text { wccess }\end{array}$ \\
(NGA) & $\begin{array}{l}\text { characteristics (such as higher throughput) as compared to those } \\
\text { provided over already existing copper networks (European Commission, }\end{array}$ \\
Wi-Fi & $\begin{array}{l}\text { 2021b). } \\
\text { Wireless Fidelity. Certification mark issued by the Wi-Fi Alliance to certify }\end{array}$ \\
& $\begin{array}{l}\text { that a product conforms to the } 802.11 \mathrm{~b}, \mathrm{~g} \text { and standards for WLANs } \\
\text { (Gartner, 2021). }\end{array}$
\end{tabular}

Minges, 2016; Bertschek et al., 2016). A number of cross-country studies focusing on the early 2000 s pointed to a 10 percentage point increase in fixed broadband penetration yielding an increase in per capita gross domestic product (GDP) growth of 0.25 to 1.5 percentage points (Czernich et al., 2011; Qiang et al., 2009). However, studies that avail of more up-to-date datasets and longer time spans have produced a wider range of estimates. These studies have also coincided with rapid advances in broadband speeds and greater public investment in digital infrastructure. Koutroumpis (2019), for example, in a study of 35 OECD countries over a 15-year period (2002-2016), found that increased broadband adoption over that period led to an average increase in GDP of $0.3 \%$ per annum. Enhanced broadband speed has also been found by Koutroumpis (2019) to exert a positive economic impact, albeit at a diminishing rate until a market saturation point is reached.

This incremental contribution of high-speed broadband to economic growth has been the focus of a number of recent empirical studies. Briglauer and Gugler (2018), for example, in a study of the EU27 member states over the period 2003 to 2015 find a small but significant effect of ultra-fast fibre-based broadband adoption (0.002-0.005\% of GDP) over and above the effects of basic broadband on GDP. The positive impact of increased broadband speed is also found by Kongaut and Bohlin (2017) in their study of OECD countries, with the authors concluding that a $10 \%$ increase in average broadband download speed positively impacts GDP per capita by $0.8 \%$. 
Empirical studies have also sought to distinguish between fixed broadband and mobile broadband penetration. Katz and Callorda (2018a), have estimated, based on a set of 139 countries over the period 2010-2017, a $1 \%$ increase in mobile broadband penetration yields almost twice as large an increase in GDP than a $1 \%$ increase in fixed broadband penetration. According to the authors, the impact of mobile broadband penetration is likely to be higher in lower income countries where market saturation has not been reached and the impact of incremental increases in mobile broadband penetration on economic growth has yet to encounter diminishing returns.

The positive economic impact associated with broadband availability and increased broadband speed has also been evident at a regional level. Briglauer et al. (2021), in a study of 401 German counties over the period 2010 to 2015, find that an increase in average broadband speed had a significantly positive effect on county-level GDP, with an increase in average bandwidth speed by one unit (1 Mpbs) bringing about a rise in county-level GDP of $0.18 \%$. What is more, when positive regional externalities across counties are taken into account, the effect is almost doubled $(0.31 \%)$.

\subsubsection{Households and Digital Connectivity}

At a micro-level, research suggests that high-speed broadband contributes positively to household income levels. Rohman and Bohlin (2013), in a study of eight OECD countries and three BRIC countries (Brazil, India and China), found that those households who did not have high-speed broadband (2-4 Mbps at that time) resulted in a difference of c. US\$2 100 per household per year (c. US\$182 per month). For Brazil, India and China, additional annual household income of US $\$ 800$ is expected to be gained by introducing $0.5 \mathrm{Mbps}$ broadband connection (US $\$ 70$ per month per household).

As noted by Dutz et al. (2009, 2012), high-speed home broadband connectivity has transformed the daily routines, consumption patterns, and information exchange of households across the globe. Economic efficiencies - such as remote working, at-home entrepreneurship, and online job searching - are merely the tip of the iceberg. A vast range of knowledge-based activities and commercial interactions-relating to e-commerce, education, entertainment, health care, news and information, personal finances, social networking, and interactions with 
government-can now be undertaken online. Given recent COVIDrelated restrictions on public gatherings, households have become even more reliant on digital connectivity. In particular, broadband has facilitated more flexible patterns of work in the form of teleworking, as well as a rapid shift of education provision to virtual and blended formats.

A 2015 report from the UK-based Centre for Economics and Business Research (CEBR) has sought to categorise and quantify the array of economic impacts accruing from enhanced digital connectivity and digital skills. These include employability benefits and an estimated earnings premium of 3\%-10\% for people who acquire digital skills; retail transaction benefits, with evidence showing that shopping online saves individuals on average $13 \%$ compared to if they were to shop in-store; time-saving benefits via rapid access to government services and swift completion of online banking transactions; and communications benefits, as individuals connect and communicate with their community, friends and families more frequently.

\subsubsection{Firm-Level Productivity and Entrepreneurship}

Existing research also explores the impact of enhanced IDC on the labour market, employee and firm-level productivity, and new firm formation. The impact of connectivity appears to manifest itself in an uneven manner: enhanced IDC appears to complement high skilled workers and highly productive firms-both of which tend to be geographically concentrated in particular regions.

Microeconomic studies have not yielded unanimous evidence of positive productivity effects of IDC on the firm level. Colombo et al. (2013), based on a sample of 799 Italian SMEs from 1998-2004, found that adoption of basic broadband applications did not increase firm-level productivity. However, SMEs that adopted advanced broadband applications did experience productivity gains, though this was contigent on these applications being industry-specific (e.g., supply chain and client management applications in manufacturing) and the SMEs augmenting them with firm-level strategic or organisational changes. Advanced broadband is also found to positively contribute to firm-level productivity in Canzian et al. (2019). This study of the impact of upgraded broadband (up to 20 Mbps download; up to 1 Mbps upload) in Trento (Italy) from 2011-2014 found that upgraded broadband was associated with increases in both firm revenue and total factor productivity. 
However, the productivity impact of ultra-fast broadband networks has been shown to exhibit marked spatial, sectoral, and occupational disparities. Hasbi (2020), in a study of almost 5000 municipalities in metropolitan France from 2010 to 2015, finds that municipalities with ultra-fast broadband networks enjoy higher firm formation in services activities, rather than across industry more generally. Similarly, Mack and Faggian (2013) and McCoy et al. (2016) find that broadband brings greater productivity benefits to regions that possess high skilled firms and high levels of human capital. These spatial disparities are indicative of what has been referred to in previous chapters as the "digital divide". Indeed, as noted by Philip et al. (2017) and Ali et al. (2020), this digital divide is most usefully understood as referring not only to inequalities in the provision of technological infrastructure required to support digital connectivity, but also as a wider socio-economic digital divide in which factors such as geographic remoteness and social exclusion create barriers to digital adoption and use in rural areas.

Specific to sectoral disparities, Haller and Lyons (2019), in a study of Irish services firms from 2002 to 2009, assess whether or not the introduction of digital subscriber line (DSL) broadband services increased firms' productivity in the services sector in Ireland from 2006 to 2012. While they did not find significant productivity effects across the services sector as a whole, they did find positive significant effects on firm's total factor productivity in Information and Communication and Administrative and Support Services. In contrast, a previous study by the same authors (Haller \& Lyons, 2015), found no evidence that broadband adoption led to higher firm productivity across a sample of 2290 Irish manufacturing firms over the same time period. The extent to which broadband adoption manifests itself as a skill-biased technological change that favours high skilled occupational groups is considered by Akerman et al. (2015) in a study of Norwegian firms over the period 2001-2007. Akerman and coauthors find that broadband adoption complements the skillsets of skilled workers and thereby increases their productivity, whereas it substitutes for routine tasks formerly undertaken by unskilled workers and ultimately lowers their productivity.

\subsubsection{Employment Impact of Digital Connectivity}

While the empirical evidence outlined above provides indications of digital connectivity enhancing productivity of existing skilled workers 
and skill-intensive regions or municipalities, evidence of new employment being created as a direct result of broadband adoption has been less clear cut. For example, Fabling and Grimes (2021)—utilising Statistics New Zealand's Longitudinal Business Database, which surveys approximately 7500 firms annually-find that over the period 2008 to 2018 ultrafast broadband adoption had a positive impact on firm-level productivity within a four-year time horizon, but a negative impact on employment. While positive productivity effects were evident among firms that had also made complementary investments, negative employment effects were observed among firms with initial low computer intensity. Briglauer et al. (2019), evaluating the impact of a European state aid programme for speed upgrades in broadband internet availability to rural areas in the German state of Bavaria throughout 2010 and 2011 , find that those municipalities with greater broadband coverage at relatively higher speed did not, on average, experience an increase in local jobs per resident.

A number of early US studies found that greater broadband availability positively impacts upon employment growth across zip-code areas (Lehr et al., 2006; Kolko, 2012). However, recent US studies focusing on the employment impact of increased broadband speeds provide conflicting results. Ford (2018), in a study of broadband speed differentials ( $10 \mathrm{Mbps}$ versus $25 \mathrm{Mbps}$ ) across US counties for the years 2013 to 2015 , finds no evidence of counties that predominantly use 25 Mbps broadband connections enjoying higher employment growth than those with $10 \mathrm{Mbps}$ connections. In contrast, Lobo et al. (2020)exploring the effects of broadband speed on county unemployment rates within the U.S. state of Tennessee over the period 2011 to 2016 find that unemployment rates were 0.26 percentage points lower in counties with high speeds compared to counties with low speeds, with better quality broadband appearing to have a disproportionately greater effect in rural areas.

However, recent studies from beyond EU and US contexts have identified both productivity and employment gains associated with digital connectivity. Chen et al. (2020) in a study of Chinese firms over the period 1998-2007 find that high-speed internet significantly increases firm's productivity and worker's wage, albeit with the impact being larger for firms in industries with high skill intensity and for more educated workers. Hjort and Poulsen (2019), using firm-level data for 12 African countries 
over the period 2006 to 2014 , find that fast internet availability in the observed African countries leads to employment increases in higher-skill occupations, but also employment gains (albeit of a relatively smaller magnitude) for less educated worker. The employment benefits manifest themselves through a variety of channels, such as greater firm entry in South Africa; higher firm level productivity among existing Ethiopian manufacturing firms; and by an increase in exports, on-the-job training, and use of online communication among firms in a further six African countries.

\subsection{Free and Municipal Wi-Fi}

Public Wi-Fi network access is the provision of broadband Internet services to the public in spaces other than the home or office, under nondiscriminatory terms and conditions (Fuentes-Bautista \& Inagaki, 2005). In this context, "public" refers to availability of the networks that provide public benefits, and therefore serve the public interest, in the form of wireless connectivity as a service to passing users (Clement \& Potter, 2008; Bar \& Galperin, 2004). The network may be owned or provided by government, communities or local businesses who typically provide use of the network at low cost or free of charge (Lehr \& McKnight, 2003) in small localised spaces (e.g., libraries, shopping centres, coffee shops or hotels), or on a larger scale (e.g., municipal, city-wide or town-wide networks). Picco-Schwendener et al. (2018) identifies three main types of public WiFi networks:

1. Municipal Wireless Networks (MWNs)—the local public administration provides Wi-Fi Internet access across a whole city or town, or a section of it, in order to serve the public interest.

2. Community Wireless Networks (CWNs) - residents in a community share part of their wired home Internet connectivity with other people of the community using Wi-Fi technology. The providers of CWNs typically have a social motivation.

3. Commercial providers-businesses provide public wireless internet access to further a business purpose. 
Table 6.2 Six developed countries: value of free Wi-Fi 2018 and 2023 (Katz \& Callorda, 2018b)

\begin{tabular}{lll}
\hline Country & $\begin{array}{l}\text { Economic surplus (in US\$ } \\
\text { billions) } \\
2018\end{array}$ & $\begin{array}{l}\text { Economic surplus (in US\$ } \\
\text { billions) } \\
2023\end{array}$ \\
\hline United States & 7.36 & 8.52 \\
United Kingdom & 0.26 & 0.25 \\
France & 0.11 & 0.12 \\
Germany & 0.30 & 0.36 \\
Japan & 1.44 & 2.03 \\
South Korea & 1.53 & 1.63 \\
\hline
\end{tabular}

The primary economic benefit of free public Wi-Fi is derived from the savings that consumers benefit from by accessing the Internet through sites offering free public Wi-Fi rather than relying on their mobile data plan. A study on future access to public Wi-Fi suggested that $60 \%$ of UK total mobile traffic will be offloaded to Wi-Fi in 2019 and of that approx. $4.32 \%$ will be free (Katz \& Callorda, 2018b). This projection signals further potential savings to the consumer generated by greater access to public Wi-Fi. While the total value of this consumer surplus is significant (see Table 6.2), it is not without controversy, not least because it may represent unfair competition to existing telecommunications providers (Potts, 2014).

As well as the direct consumer surplus described above, the benefits of free municipal public Wi-Fi access include economic development, community branding, collaboration between other public service providers in a municipality, provision of internet connectivity (and associated services) to low-income and underserved citizens, and revenue generating activities (see Table 6.3).

It is noteworthy that free public Wi-Fi forms part of the European Tourism Manifesto for Growth and Jobs (European Tourism Manifesto Alliance, 2017). Item 7 of the manifesto emphasises, amongst other things, that the EU should encourage free Wi-Fi for visitors in tourist attractions, events and destinations (European Tourism Manifesto Alliance, 2017). 
Table 6.3 Motivations and anticipated benefits for MWNs (adapted and extended from Picco-Schwendener et al., 2018)

\begin{tabular}{|c|c|c|}
\hline Motivation & Benefits & Sources \\
\hline $\begin{array}{l}\text { Economic } \\
\text { development }\end{array}$ & $\begin{array}{l}\text { Fosters growth, efficiency, } \\
\text { productivity, innovation and } \\
\text { competitiveness. } \\
\text { Creates and increases destination } \\
\text { and/or market attractiveness. } \\
\text { Stimulates competition. } \\
\text { Encourages local innovation including } \\
\text { improved municipal services and } \\
\text { applications. }\end{array}$ & $\begin{array}{l}\text { Yovanof and Hazapis (2009), } \\
\text { Lambert et al. (2014), Ojala } \\
\text { et al. (2008). } \\
\text { Bar and Galperin }(2004,2005) \text {, } \\
\text { Middleton (2007). } \\
\text { Infante et al. (2007). } \\
\text { Ballon et al. (2009), Fuentes- } \\
\text { Bautista and Inagaki (2005), } \\
\text { Heer et al. (2010), Infante et al. } \\
(2007) \text {, Middleton et al. (2006, } \\
2008) \text {. }\end{array}$ \\
\hline \multirow[t]{2}{*}{$\begin{array}{l}\text { Promoting } \\
\text { tourism }\end{array}$} & $\begin{array}{l}\text { Provides internet connectivity to } \\
\text { international visitors and thus avoids } \\
\text { roaming costs; transforms public } \\
\text { spaces in to productive spaces. }\end{array}$ & $\begin{array}{l}\text { Heer et al. (2010), Ballon et al. } \\
\text { (2009), Lambert et al. (2014), } \\
\text { Ojala et al. (2008), Tapia and } \\
\text { Ortiz (2008), Van Audenhove } \\
\text { et al. (2007). }\end{array}$ \\
\hline & $\begin{array}{l}\text { Provides information and/or brings } \\
\text { people to attractions or special places } \\
\text { of interest incl. conferences. }\end{array}$ & $\begin{array}{l}\text { Forlano (2008), Hampton and } \\
\text { Gupta (2008), Picco- } \\
\text { Schwendener et al. (2018), } \\
\text { Mandviwalla et al. (2008). }\end{array}$ \\
\hline \multirow[t]{2}{*}{$\begin{array}{l}\text { Social } \\
\text { inclusion }\end{array}$} & Serves a public good/utility & $\begin{array}{l}\text { Clark (2002), Middleton et al. } \\
(2006,2007) \text {. }\end{array}$ \\
\hline & $\begin{array}{l}\text { Fosters civic participation and social } \\
\text { engagement. }\end{array}$ & $\begin{array}{l}\text { Chesley (2009), Bar and Park } \\
\text { (2005), Hampton et al. (2010). }\end{array}$ \\
\hline Public safety & $\begin{array}{l}\text { Facilitates the two-way sharing of } \\
\text { information on issues of public safety. }\end{array}$ & $\begin{array}{l}\text { Chesley (2009), Tapia and Ortiz } \\
\text { (2008), Tapia et al. (2011). }\end{array}$ \\
\hline $\begin{array}{l}\text { Improved } \\
\text { public service }\end{array}$ & $\begin{array}{l}\text { Provides internet connectivity to } \\
\text { employees working in public spaces. } \\
\text { Simplifies exchange of information. } \\
\text { Yields telecommunications cost } \\
\text { savings. }\end{array}$ & $\begin{array}{l}\text { Ballon et al. (2009), Bar and } \\
\text { Park (2005). } \\
\text { Heer et al. (2010). } \\
\text { Ballon et al. (2009), Bar and } \\
\text { Park (2005), Infante et al. } \\
(2007) .\end{array}$ \\
\hline
\end{tabular}

\subsection{Rural Digital Hubs}

Rural digital hubs have been proposed as a potential solution to improve broadband connectivity, improve digital literacy for individuals, workers and businesses, attract new residents and visitors, and stimulate economic activity (European Network for Rural Development, 2017). Refining the European Network for Rural Development (ENRD) working definition of 
rural digital hubs (ENRD, 2017), Rundel et al. (2018, p. 1) define a rural digital hub as "a physical space, which can be fixed or mobile, focused on digital connectivity, digital skill development and/or emergent technologies." They are not a new idea. Indeed, they merely represent the latest wave of optimism for what was referred to as telecottages in the 1990s and telecentres in the 2000s (Moriset, 2011). They have become an increasing part of policy responses during the COVID-19 pandemic to support remote working and indeed rural digital hubs and co-working spaces report renewed optimism for the sector backed by state and corporate support for remote working (Tomaz et al., 2021). For example, the Irish government launched a National Hub Network and support funding for up to 380 remote working hubs (Department of Rural and Community Development, 2021).

Consistent with the telecentre literature (Moriset, 2011), in their recent analysis of rural digital hubs, Rundel et al. (2020) note that such hubs can be organised into hubs for businesses, hubs for communities, and hubs for both sets of stakeholders. Similarly, they may be standalone or co-located in libraries or community centres (Rundel et al., 2020). They also note that while the ENRD (2017) aspired for rural digital hubs to play an active role in improving digital literacy, in reality few offered such services or indeed recognise themselves as a digital hub, and where offered these services required payment (Rundel et al., 2020). As a result, accessibility issues may not be addressed satisfactorily. The ENRD (2017) notes that committed leaders and community engagement are critical success factors for rural digital hubs initiative, and that rural digital hubs should form part of a wider strategic vision for a town. It is also important to note that the establishment and sustainability of such hubs requires a mix of funding from local and national authorities but also the private sector through sponsorship (ENRD, 2017). This suggests high levels of both vertical and horizontal integration are needed, a subject that will be discussed later in Chap. 8.

\subsection{MEASUring InFrastructure FOR Digital CONNECTIVITY}

The manner in which digital connectivity impacts upon economic outcomes also gives rise to numerous measurement problems. As Canzian et al. (2019) note, digital connectivity is best characterised as a "general purpose technology" and, as such, its positive impact on economic outcomes most likely takes the form of growth-enhancing externalities that enhance all economic activities and social interactions. But as Abrardi and Cambini (2019) point out, empirical measurement of such externalities has proven to be problematic, as it seeks to quantify the effects of 
high-speed broadband diffusion in terms of economic metrics rather than as network effects. What is more, available data points to a low take up of ultra-fast broadband-something which may underestimate the full extent of potential network effects which can accrue from digital connectivity. Briglauer and Gugler (2018) note that, across the EU member states in 2015 , basic broadband take-up rates $(72.50 \%)$ were much larger than for hybrid $(20.59 \%)$ and end-to-end fibre-based (25.91\%) broadband. While recent data suggests that high-speed fibre Internet connections surpassed copper-wire DSL connections in the OECD for the first time in 2020 (OECD, 2021), there would seem to be persistent gaps between urban and rural areas in terms of ultrafast broadband availability (OECD, 2020). This low take-up may be due to consumers opting for satisfactory basic broadband rather than switching to more expensive high-speed alternatives. Should measurement difficulties - compounded by low take-up of high-speed broadband-lead to the positive overall welfare contribution of digital connectivity being underestimated, cost-benefit analyses might not be supportive of additional public investment in digital infrastructure provision.

As per Table 6.4, IDC features in most major international measurement frameworks and composite indices to varying degrees. Reflecting the literature, the availability and adoption of broadband is a significant focus. Some frameworks include additional relevant indicators including:

- 5G readiness-Digital Economy and Skills Unit (2018, 2020, 2021);

- Access settings, time spent online and support and training-Digital Capital Index (Ragnedda et al., 2020);

- Secure Internet Infrastructure-Digital Capital Index (Ragnedda et al., 2020); G20 Toolkit for Measuring the Digital Economy (G20 Digital Economy Task Force, 2018);

- Institutional and regulatory-G20 Toolkit for Measuring the Digital Economy (G20 Digital Economy Task Force, 2018);

- Infrastructure for the Internet of Things-G20 Toolkit for Measuring the Digital Economy (G20 Digital Economy Task Force, 2018).

Interestingly only two frameworks include access to electricity (the Digital Evolution Index and the Partnership on Measuring ICT for Development), and only one includes public access to Wi-Fi (CityKeys).

Unlike data for other topics discussed in this book, it is worth noting that data on IDC is typically collected and reported regularly by national 
Table 6.4 Selected Infrastructure for Digital Connectivity indicators by international digital society and digital economy measurement frameworks and composite indices

\begin{tabular}{|c|c|}
\hline Indicator category & Selected international frameworks and composite indices \\
\hline & Digital Planet-Digital Evolution Index (Chakravorti et al., 2015); \\
\hline electricity & Partnership on Measuring ICT for Development (ITU, 2021) \\
\hline fixed and mobile & CityKeys (Bosch et al., 2017); DESI (Digital Economy and Skills \\
\hline broadband & Unit, 2018, 2020, 2021); Digital Planet-Digital Evolution Index \\
\hline penetration (incl. & (Chakravorti et al., 2015); Digital Ecosystem Development Index \\
\hline by service quality) & (Katz et al., 2014; Katz \& Callorda, 2018a); G20 Toolkit for \\
\hline & $\begin{array}{l}\text { Measuring the Digital Economy (G20 Digital Economy Task Force, } \\
\text { 2018); ICT Development Index (ITU, 2016), I-DESI (Foley et al., } \\
\text { 2018); Partnership on Measuring ICT for Development (ITU, 2021). }\end{array}$ \\
\hline \multirow{8}{*}{$\begin{array}{l}\text { Device } \\
\text { penetration }\end{array}$} & DESI (Digital Economy and Skills Unit $(2018,2020,2021)$; Digital \\
\hline & Capital Index (Ragnedda et al., 2020); Digital Planet—Digital \\
\hline & Evolution Index (Chakravorti et al., 2015); Digital Ecosystem \\
\hline & Development Index (Katz et al., 2014; Katz \& Callorda, 2018a); \\
\hline & G20 Toolkit for Measuring the Digital Economy (G20 Digital \\
\hline & Economy Task Force, 2018); ICT Development Index (ITU, 2016), \\
\hline & I-DESI (Foley et al., 2018); Partnership on Measuring ICT for \\
\hline & Development (ITU, 2021). \\
\hline \multirow{6}{*}{$\begin{array}{l}\text { Fixed and mobile } \\
\text { broadband } \\
\text { coverage (incl. by } \\
\text { service quality) }\end{array}$} & DESI (Digital Economy and Skills Unit $(2018,2020,2021)$; Digital \\
\hline & Planet-Digital Evolution Index (Chakravorti et al., 2015); Digital \\
\hline & Ecosystem Development Index (Katz et al., 2014; Katz \& Callorda, \\
\hline & 2018a); G20 Toolkit for Measuring the Digital Economy (G20 \\
\hline & Digital Economy Task Force, 2018); ICT Development Index (ITU, \\
\hline & $\begin{array}{l}\text { 2016), I-DESI (Foley et al., 2018); Partnership on Measuring ICT } \\
\text { for Development (ITU, 2021). }\end{array}$ \\
\hline \multirow{4}{*}{$\begin{array}{l}\text { Pricing and } \\
\text { affordability }\end{array}$} & Digital Planet-Digital Evolution Index (Chakravorti et al., 2015); \\
\hline & G20 Toolkit for Measuring the Digital Economy (G20 Digital \\
\hline & Economy Task Force, 2018); ICT Development Index (ITU, 2016); \\
\hline & Partnership on Measuring ICT for Development (ITU, 2021). \\
\hline
\end{tabular}

sources, often at high levels of granularity including towns and their environs. International benchmark data is also widely available. Commonly cited international sources include:

- EU Broadband Coverage in Europe Studies

- EU Broadband Internet Access (BIAC) survey

- European Broadband Mapping Portal

- EU Communications Committee survey

- Eurostat

- ITU World Telecommunication/ICT Indicators database 
- OECD Broadband portal

- UNESCO Institute for Statistics

IDC cannot be examined in isolation. As noted above and in previous chapters, the skills-bias inherent in digitalisation, as a whole, brings with it the risk of creating economic winners and losers. Abrardi and Cambini $(2019$, p. 184) neatly summarise the risks posed to employees and firms who find themselves on the losing side:

While higher productivity could translate into higher wages, firms might as well shed staff in response to the increased automation. Differences in income between skilled and non-skilled workers could increase, as broadband is complementary to human capital. Moreover, if broadband increases competition, some firms will lose staff or go out of business altogether.

The spatial manifestation of disparities associated with digital connectivity is, of course, one aspect of the "digital divide" referred to in previous chapters. As Ford (2018, p. 775) points out, "broadband is not randomly distributed across geography, but rather is deployed in areas where the ratio of demand to costs is favorable, complicating the task of discovering broadband's influence on economic outcomes." Lower population densities and greater distances in rural areas discourage private sector actors from investing in new technologies, re-enforcing this digital divide between urban and rural communities. Salemink et al. (2017), in a review of 157 papers on digital developments and regional growth, find a persistent and widening gap in data infrastructure quality between urban and rural areas, with public policies aimed at promoting the availability or improvement of data infrastructure becoming rapidly outdated by market developments. As such, more granular analysis at the level of towns and sparsely populated areas is required.

\subsection{Conclusion}

In studies of the economic benefits accruing from technological advances, references to eminent economist Robert Solow's quip that "you can see the computer age everywhere but in the productivity statistics" have become ubiquitous. ${ }^{2}$ While it may be tempting to declare that Solow's

${ }^{2}$ Solow, Robert M. 1987. "We'd Better Watch Out" review of Manufacturing Matters: The Myth of the Post-Industrial Economy, by Stephen S. Cohen and John Zysman, New York Times, July 12, 1987. 
productivity paradox has now been resolved, such a conclusion appears to be premature. ${ }^{3}$ As discussed above, it would appear that instead the paradox noted by Solow is more akin to-to borrow another oft-cited phrase, albeit from an entirely different context- "a riddle, wrapped in a mystery, inside an enigma". ${ }^{4}$ While the majority of empirical studies examined in this chapter document positive impacts of digital connectivity on GDP, firm-level productivity, and-to a lesser extent-employment, the effects of digital connectivity are characterised by a marked social, spatial, and occupational disparities. So, rather than resolving Solow's productivity paradox, a host of further puzzles have emerged. These issues relate primarily to the digital divide. For example, should the digital divide be understood merely in terms of uneven roll-out of digital infrastructure or as a wider societal inequality? Will greater digital connectivity benefit both rural and urban regions, or indeed low-income and high-income countries, or will existing regional and national disparities persist? Do the benefits of digital connectivity only accrue to high-skilled workers and those firms which possess the requisite organisational structures? While empirical studies have in recent years begun to engage with these questions, conclusive answers have yet to materialise.

There is an onus on policymakers to respond to the inequalities that arise due to the emergence of new digital technologies and, indeed, to use new technologies to bridge existing economic and societal "digital divides". The crafting of such digitally-informed economic, social, and regional policies has become all the more pertinent in the post-pandemic context. 5G mobile access networks are expected to have a greater impact than previous network shifts, enabling new classes of advanced applications, fostering business innovation and spurring economic growth (IHS, 2019). However, as this chapter illustrates, such far-reaching digital advances can bring great economic and societal benefits but can also see certain social groups and regions left behind. The challenge facing policy makers in the coming years will be to ensure that no-one is left disconnected.

${ }^{3}$ For a recent debate regarding the productivity paradox, see Brynjolfsson and McAfee (2011) who argue that US workplaces have been transformed by advances in ICT and Acemoglu et al. (2014) who call for further direct evidence regarding the IT-induced transformation of the US economy.

${ }^{4}$ Winston Churchill (1 October, 1939) The Russian Enigma. (BBC Broadcast), London. 


\section{REFERENCES}

Abrardi, L., \& Cambini, C. (2019). Ultra-fast broadband investment and adoption: A survey. Telecommunications Policy, 43(3), 183-198.

Acemoglu, D., Dorn, D., Hanson, G. H., \& Price, B. (2014). Return of the Solow paradox? IT, productivity, and employment in US manufacturing. American Economic Review, 104(5), 394-399.

Ali, M.A., Alam, K., \& Taylor, B. (2020). Do social exclusion and remoteness explain the digital divide in Australia? Evidence from a panel data estimation approach. Economics of innovation and new technology, 29(6), 643-659.

Akerman, A., Gaarder, I., \& Mogstad, M. (2015). The skill complementarity of broadband internet. The Quarterly Journal of Economics, 130(4), 1781-1824.

Ballon, P., Van Audenhove, L., Poel, M., \& Staelens, T. (2009). Business models for wireless city networks in the EU and the US: Public inputs and public leverage. In Telecommunication markets (pp. 325-340). Springer.

Bar, F., \& Galperin, H. (2004). Building the wireless internet infrastructure: From cordless ethernet archipelagos to wireless grids. Communications and Strategies, $54(2), 45-68$.

Bar, F., \& Galperin, H. (2005). Geeks, bureaucrats and cowboys: Deploying internet infrastructure, the wireless way. In The network society: From knowledge to policy, Center for Transatlantic Relations (p. 269).

Bar, F., \& Park, N. (2005). Municipal Wi-Fi networks: The goals, practices, and policy implications of the US case. Communications and Strategies, 61(1), 107-124.

Bertschek, I., Briglauer, W., Hüschelrath, K., Kauf, B., \& Niebel, T. (2016). The economic impacts of broadband internet: A survey. Review of Network Economics, 14(4), 201-227.

Bosch, P., Jongeneel, S., Rovers, V., Neumann, H. M., Airaksinen, M., \& Huovila, A. (2017). CITYkeys list of city indicators. CityKeys. http://nws.eurocities. $\mathrm{eu} /$ MediaShell/media/CITYkeyslistofcityindicators.pdf

Briglauer, W. \& Gugler, K. P. (2018). Go for Gigabit? First Evidence on Economic Benefits of (Ultra-)Fast Broadband Technologies in Europe. ZEW - Centre for European Economic Research Discussion Paper No. 18-020, Available at SSRN: https: / /ssrn.com/abstract $=3165417$

Briglauer, W., Dürr, N., Falck, O., \& Hüschelrath, K. (2019). Does state aid for broadband deployment in rural areas close the digital and economic divide? Information Economics and Policy, 46, 68-85.

Briglauer, W., Dürr, N., \& Gugler, K. (2021). A retrospective study on the regional benefits and spillover effects of high-speed broadband networks: Evidence from German counties. International Journal of Industrial Organization, $74,102677$.

Briglauer, W., \& Gugler, K. (2019). Go for gigabit? First evidence on economic benefits of high-speed broadband technologies in Europe. JCMS: Journal of Common Market Studies, 57(5), 1071-1090. 
Brynjolfsson, E., \& McAfee, A. (2011). Race against the machine: How the digital revolution is accelerating innovation, driving productivity, and irreversibly transforming employment and the economy. Digital Frontier Press.

Canzian, G., Poy, S., \& Schüller, S. (2019). Broadband upgrade and firm performance in rural areas: Quasi-experimental evidence. Regional Science and Urban Economics, 77, 87-103.

Chakravorti, B., Chaturvedi, R., \& Tunnard, C. (2015). Where the digital economy is moving the fastest. Harvard Business Review. https://hbr. org/2015/02/where-the-digital-economy-is-moving-the-fastest

Chen, S., Liu, W., \& Song, H. (2020). Broadband internet, firm performance, and worker welfare: Evidence and mechanism. Economic Inquiry, 58(3), 1146-1166.

Chesley, K. A. (2009). The future of municipal wireless in the United States and Europe. Available at SSRN 1408808.

Clark, B. (2002). The wireless "napsterization” of broadband access. Gartner Group. http://www.bus.umich.edu/kresgepublic/journals/gartner/research/ 110100/110146/110146.pdf

Clement, A., \& Potter, A. (2008). Saving Toronto Hydro Telecom's One Zone project from itself: Alternative models for urban public wireless infrastructure. The Journal of Community Informatics, 4(1), pp. 1-4.

Colombo, M. G., Croce, A., \& Grilli, L. (2013). ICT services and small businesses' productivity gains: An analysis of the adoption of broadband Internet technology. Information Economics and Policy, 25(3), 171-189.

Czernich, N., Falck, O., Kretschmer, T., \& Woessman, L. (2011). Broadband infrastructure and economic growth. The Economic Journal, 121, 505-532.

Department of Rural and Community Development. (2021). Our rural future: Minister Humphreys announces $€ 8.8$ million in funding under the Connected Hubs Scheme. https://www.gov.ie/en/press-release/a6253-our-rural-futureminister-humphreys-announces-88-million-in-funding-under-the-connectedhubs-scheme/

Digital Economy and Skills Unit. (2018) The digital economy and society index (DESI) methodological note. https://ec.europa.eu/information_society/ newsroom/image/document/2018-20/desi-2018-methodology_ E886EDCA-B32A-AEFB-07F5911DE975477B_52297.pdf

Digital Economy and Skills Unit. (2020). DESI 2020-Digital economy and society index (DESI) 2020 questions and answers. https://ec.europa.eu/commission/presscorner/detail/en/qanda/20/1022

Digital Economy and Skills Unit. (2021) The digital economy and society index (DESI) 2020. https://ec.europa.eu/newsroom/dae/document.cfm?doc_id= 67086

Dutz, M., Orszag, J., \& Willig, R. (2009). The substantial consumer benefits of broadband connectivity for US households. Internet Innovation Alliance.

Dutz, M. A., Orszag, J. M., \& Willig, R. D. (2012). The liftoff of consumer benefits from the broadband revolution. Review of Network Economics, 11(4). 
European Commission. (2021a). 2030 digital compass: The European way for the digital decade. https://eur-lex.europa.eu/legal-content/en/TXT/?uri=CEL EX\%3A52021DC0118

European Commission. (2021b). Broadband Glossary. https://digital-strategy. ec.europa.eu/en/policies/broadband-glossary

European Commission. (2021c). Broadband: Technology overview. https:// digital-strategy.ec.europa.eu/en/policies/broadband-technology-overview

European Network for Rural Development. (2017). Revitalising rural areas through digitisation the experience of three rural digital hubs. https://enrd. ec.europa.eu/sites/default/files/tg_rural-businesses_case-study_ruraldigital-hub_0.pdf

European Tourism Manifesto Alliance. (2017). European Tourism Manifesto. https://tourismmanifesto.eu/manifesto/en-tourism-manifesto.pdf

Fabling, R., \& Grimes. A. (2021). Picking up speed: Does ultrafast broadband increase firm productivity? Information Economics and Policy, 100937.

Foley, P., Sutton, D., Wiseman, I., Green, L., \& Moore, J. (2018). International digital economy and society index 2018. The European Commission, Directorate-General of Communications Networks, Content and Technology.

Ford, G. S. (2018). Is faster better? Quantifying the relationship between broadband speed and economic growth. Telecommunications Policy, 42(9), 766-777.

Forlano, L. (2008). Anytime? Anywhere?: Reframing debates around municipal wireless networking. Journal of Community Informatics, 4(1), pp. 1-23.

Freedom House. (2020). Freedom on the Internet. https://freedomhouse.org/ sites/default/files/2020-10/10122020_FOTN2020_Complete_ Report_FINAL.pdf

Fuentes-Bautista, M., \& Inagaki, N. (2005). Wi-Fi's promise and broadband divides: Reconfiguring public internet access in Austin, Texas. Telecommunication Policy Research Conference, Arlington, VA.

G20 Digital Economy Task Force (DETF). (2018). G20 toolkit for measuring the digital economy. OECD. https://www.oecd.org/g20/summits/buenosaires/G20-Toolkit-for-measuring-digital-economy.pdf

Gartner. (2021). Information Technology Glossary. https://www.gartner.com/ en/information-technology/glossary/

Haleem, A., Allen, A., Thompson, A., Nijdam, M., \& Garg, R. (2018). Helium: A decentralized wireless network. Helium Systems Inc., Tech. Rep. http:// whitepaper.helium.com

Haller, S. A., \& Lyons, S. (2015). Broadband adoption and firm productivity: Evidence from Irish manufacturing firms. Telecommunications Policy, $39(1), 1-13$.

Haller, S. A., \& Lyons, S. (2019). Effects of broadband availability on total factor productivity in service sector firms: Evidence from Ireland. Telecommunications Policy, 43(1), 11-22. 
Hampton, K. N., \& Gupta, N. (2008). Community and social interaction in the wireless city: Wi-fi use in public and semi-public spaces. New Media o Society, $10(6), 831-850$.

Hampton, K. N., Livio, O., \& Sessions Goulet, L. (2010). The social life of wireless urban spaces: Internet use, social networks, and the public realm. Journal of Communication, 60(4), 701-722.

Hasbi, M. (2020). Impact of very high-speed broadband on local economic growth: Empirical evidence. Telecommunications Policy, 44, 1-21.

Heer, T., Hummen, R., Viol, N., Wirtz, H., Götz, S., \& Wehrle, K. (2010). Collaborative municipal wi-fi networks-challenges and opportunities. In Proceedings of Eighth IEEE International Conference on Pervasive Computing and Communications Workshops, Seattle, USA, pp. 588-593.

Hjort, J., \& Poulsen, J. (2019). The arrival of fast internet and employment in Africa. American Economic Review, 109(3), 1032-1079.

IEA. (2020). SDG7: Data and projections. https://www.iea.org/reports/ sdg7-data-and-projections

IHS. (2019). The 5G economy: How $5 \mathrm{G}$ will contribute to the global economy. IHS Markit.

Infante, J., Oliver, M., \& Macián, C. (2007). Which way to a (judicious) municipal wireless network? An assessment of the different alternatives for municipal participation in wireless local networks. 35th Telecommunications Policy Research Conference.

Intel. (2021). What is a hotspot?-WiFi hotspot definitions and details. https:// www.intel.com/content/www/us/en/tech-tips-and-tricks/what-is-ahotspot.html

ITU. (2012). Impact of broadband on the economy. ITU.

ITU. (2016). Core list of ICT indicators. https://www.itu.int/en/ITU-D/ Statistics/Documents/coreindicators/Core-List-of-Indicators_ March2016.pdf

ITU. (2021). The ICT Development Index (IDI): Conceptual framework and methodology. https://www.itu.int/en/ITU-D/Statistics/Pages/publications/mis/methodology.aspx

Jassem, H. C. (2010). Municipal wifi: The coda. Journal of Urban Technology, $17(2), 3-20$.

Katz, R., \& Callorda, F. (2018a). The economic contribution of broadband, digitization and ICT regulation. International Technological Union.

Katz, R., \& Callorda, F. (2018b). The economic value of Wi-Fi: A global view (2018 and 2023). Telecom Advisory Services.

Katz, R., Koutroumpis, P., \& Callorda, F. M. (2014). Using a digitization index to measure the economic and social impact of digital agendas. Info.

Kolko, J. (2012). Broadband and local growth. Journal of Urban Economics, $71(1), 100-113$. 
Kongaut, C., \& Bohlin, E. (2017). Impact of broadband speed on economic outputs: An empirical study of OECD countries. Economics and Business Review, $3(2), 12-32$.

Koutroumpis, P. (2019). The economic impact of broadband: Evidence from OECD countries. Technological Forecasting and Social Change, 148, 119719.

Lambert, A., McQuire, S., \& Papastergiadis, N. (2014). Public wi-fi: Space, sociality and the social good. Australian Journal of Telecommunications and the Digital Economy, 2(3), 45.

Lehr, W., \& McKnight, L. W. (2003). Wireless internet access: 3G vs. WiFi? Telecommunications Policy, 27(5-6), 351-370.

Lehr, W. H., Osorio, C. A., Gillett, S. E., \& Sirbu, M.A. (2006). Measuring broadband's economic impact. September Proceeding of the 33rd Research Conference on Communication, Information, and Internet Policy (TPRC) (Vol. 23-25), Arlington, VA.

Lobo, B. J., Alam, M. R., \& Whitacre, B. E. (2020). Broadband speed and unemployment rates: Data and measurement issues. Telecommunications Policy, $44(1), 101829$.

Lynn, T., Rosati, P., Fox, G., Curran, D., O'Gorman, C., \& Conway, E. (2020). Addressing the urban-town-rural divide: The digital town readiness assessment framework. In ICDS 2020: The fourteenth international conference on digital society (pp. 1-10).

Mack, E., \& Faggian, A. (2013). Productivity and broadband: The human factor. International Regional Science Review, 36(3), 392-423.

Mandviwalla, M.,Jain,A., Fesenmaier,J.,Smith,J., Weinberg,P., \& Meyers, G. (2008). Municipal broadband wireless networks. Communications of the ACM, $51(2), 72-80$.

McCoy, D., Lyons, S., Morgenroth, E., Palcic, D., \& Allen, L. (2016). The impact of local infrastructure on new business establishments.

Messié, V., Fromentoux, G., Marjou, X., \& Omnes, N. L. (2019). BALAdIN for blockchain-based 5G networks. In 2019 22nd Conference on Innovation in Clouds, Internet and Networks and Workshops (ICIN) (pp. 201-205). IEEE.

Middleton, C. (2007). A framework for investigating the value of public wireless networks. 35th Conference on Communication, Information and Internet Policy.

Middleton, C., Clement, A., Crow, B., \& Longford, G. (2008). ICT infrastructure as public infrastructure: Connecting communities to the knowledge-based economy \& society (No. n/a). Ryerson University, Toronto.

Middleton, C., Clement, A., \& Longford, G. (2006). ICT infrastructure as public infrastructure: Exploring the benefits of public wireless networks. Paper presented at the Telecommunications Policy Research Conference, Arlington, VA.

Minges M. (2016). Exploring the relationship between broadband and economic growth. Background Paper prepared for World Development Report 2016: Digital Dividends. 
Moriset, B. (2011). Developing the digital economy in French rural regions? A critical assessment of telecenters. Netcom. Réseaux, communication et territoires, $(25-3 / 4), 249-272$.

OECD. (2020). OECD digital economy outlook 2020. https://www.oecd-ilibrary. org/science-and-technology/oecd-digital-economy-outlook-2020_ bbl6704l-en

OECD. (2021). OECD broadband statistics update. https://www.oecd.org/ digital/broadband/broadband-statistics-update.htm

Ojala, T., Hakanen, T., Salmi, O., Kenttälä, M., Tiensyrjä, J., \& Närhi, P. (2008). Characterizing the usage of a large municipal WiFi network. MobiCom.

Philip, L., Cottrill, C., Farrington, J., Williams, F., \& Ashmore, F. (2017). The digital divide: Patterns, policy and scenarios for connecting the 'final few' in rural communities across Great Britain. Journal of Rural Studies, 54, 386-398.

Picco-Schwendener, A., Reinhold, H. J., \& Cantoni, L. (2018). Personalizing messages for the users of a free municipal wi-fi network (MWN): A proof of concept. Proceedings of the lst UNWTO World Conference on Smart Destinations, Murcia.

Ponzanesi, S. (2019). Migration and mobility in a digital age: (Re) mapping connectivity and belonging. Television os New Media, 20(6), 547-557.

Potts, J. (2014). Economics of public WiFi. Journal of Telecommunications and the Digital Economy, 2(1), 20-21.

Qiang, C. Z. W., Rossotto, C. M., \& Kimura, K. (2009). Economic impacts of broadband. Information and communications for development 2009: Extending reach and increasing impact, 3, 35-50.

Ragnedda, M., Ruiu, M. L., \& Addeo, F. (2020). Measuring digital capital: An empirical investigation. New Media \& Society, 22(5), 793-816.

Rohman, I. K., \& Bohlin, E. (2013). Does broadband speed really matter as a driver of economic growth? Investigating OECD countries. International Journal of Management and Network Economics 5, 2(4), 336-356.

Rubin, N. (2017). Without energy, the Internet is just a black hole: Creating energy solutions for information and communications technology. https:// a4ai.org/without-energy-the-internet-is-just-a-black-hole-creatingenergy-solutions-for-information-and-communications-technology/

Rundel, C., Salemink, K., \& Strijker, D. (2018). CORA diagnostic survey results: Results and guiding measures. https://northsearegion.eu/media/7485/corareport-diagnostic-survey-results.pdf

Rundel, C. T., Salemink, K., \& Strijker, D. (2020). Exploring rural digital hubs and their possible contribution to communities in Europe. Journal of Rural and Community Development, 15(3), 21-44.

Salemink, K., Strijker, D., \& Bosworth, G. (2017). Rural development in the digital age: A systematic literature review on unequal ICT availability, adoption, and use in rural areas. Journal of Rural Studies, 54, 360-371. 
Shafi, M., Molisch, A. F., Smith, P. J., Haustein, T., Zhu, P., De Silva, P., Tufvesson, A., Benjebbour, A., \& Wunder, G. (2017). 5G: A tutorial overview of standards, trials, challenges, deployment, and practice. IEEE Journal on Selected Areas in Communications, 35(6), 1201-1221.

Tapia, A. H., Kvasny, L., \& Ortiz, J. A. (2011). A critical discourse analysis of three US municipal wireless network initiatives for enhancing social inclusion. Telematics and Informatics, 28(3), 215-226.

Tapia, A. H., \& Ortiz, J. A. (2008). Keeping promises: Municipal communities struggle to fulfill promises to narrow the digital divide with municipal community wireless networks. The Journal of Community Informatics, 4(1), pp. 1-20.

Tomaz, E., Moriset, B., \& Teller, J. (2021). Rural coworking spaces in the Covid-19 era. A window of opportunity? https://halshs.archives-ouvertes.fr/ halshs-03235464/document

UNCTAD. (2021). Technology and innovation report 2021. United Nations Publications.

Van Audenhove, L., Ballon, P., Poel, M., \& Staelens, T. (2007). Government policy and wireless city networks: A comparative analysis of motivations, goals, services and their relation to network structure. The Southern Africa Journal of Information and Communication, 2007(8), 108-135.

Yovanof, G. S., \& Hazapis, G. N. (2009). An architectural framework and enabling wireless technologies for digital cities \& intelligent urban environments. Wireless Personal Communications, 49(3), 445-463.

Open Access This chapter is licensed under the terms of the Creative Commons Attribution 4.0 International License (http://creativecommons.org/licenses/ by $/ 4.0 /$ ), which permits use, sharing, adaptation, distribution and reproduction in any medium or format, as long as you give appropriate credit to the original author(s) and the source, provide a link to the Creative Commons licence and indicate if changes were made.

The images or other third party material in this chapter are included in the chapter's Creative Commons licence, unless indicated otherwise in a credit line to the material. If material is not included in the chapter's Creative Commons licence and your intended use is not permitted by statutory regulation or exceeds the permitted use, you will need to obtain permission directly from the copyright holder.

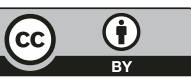

